PRZEGLĄD RUSYCYSTYCZNY 2020, $\mathrm{nr} 4$ (172)

DOI $10.31261 / \mathrm{pr} .8437$

JAKUB BOBER

Uniwersytet Śląski

(D) ORCID http://orcid.org/00oo-00o2-4200-2683

\title{
KOLEJKA WŁADIMIRA SOROKINA W POLSKIM PRZEKŁADZIE
}

\section{THE QUEUE BY VLADIMIR SOROKIN IN POLISH TRANSLATION}

The article puts forward the translation issues of the linguistic phenomenon in Vladimir Sorkin's novel The Queue. It analyzes the non-standard phenomena which constitutes a big challenge for the translator. The reasons behind this state of affairs should be sought within a selection of unconventional means of expression which revolutionized the perception of literature and its translation. Some excerpts of the novel are an attempt to provide an answer as to what degree the translator has managed to successfully portray the novel's connotation in Polish with analogical linguistic measures.

Keywords: Vladimir Sorokin, translation, non-standard phenomena

Władimir Sorokin to nie tylko jedna z czołowych postaci rosyjskiego konceptualizmu i postmodernizmu, lecz także bohater licznych skandali i aktywny uczestnik literackiej rewolucji. Jest to również pisarz, który rzucił wyzwanie tłumaczom na całym świecie, oczekując od nich, że podobnie jak on sam będą szokować czytelnika. Sorokin wzbudza kontrowersje, operując przesadzoną intymnością, opisując, jak zakochani z fantazją dokonują masowego morderstwa ${ }^{1}$. Zyskał też miano kogoś, kto z premedytacją ignoruje uznane i przyjęte wartości literackie, wyszydzając klasyków i inteligencję ${ }^{2}$. Nie przypadkiem bowiem mówi się o nim, że „wbił złoty gwóźdź w głowę wielkiej rosyjskiej

1 A. Wawrzyńczak, Zbrodnia na literaturze. Powieść „Roman” Władimira Sorokina, w: A. Gildner, M. Ochniak, H. Waszkielewicz (red.), Postmodernizm i jego antycypacje, Collegium Columbinum, Kraków 2007, s. 194.

2 W. Sorokin, Kolejka, przeł. I. Lewandowska, Tower Press, Gdańsk 2005, s. 6. 
literatury"3. Jednakże ocena Sorokina wyłącznie w kategoriach szukającego rozgłosu skandalisty, niemającego pomysłu na „przyzwoitą” twórczość, wydaje się banalna. Odbiorcy, którym przy czytaniu jego powieści towarzysza negatywne emocje, najprawdopodobniej nie zdają sobie sprawy, że autor traktuje literaturę wyłącznie jak kartkę pokrytą czarną farbą. Pisarz wielokrotnie prowokacyjnie stwierdzał w wywiadach, że „literatura to jedynie papier pokryty gryzmołami”4. Twórczość literacka dla Sorokina to przede wszystkim eksperymenty i gry językowe. Tytuły większości jego powieści traktować należy jako słowa-klucze, ponieważ niemal zawsze stanowią one wprowadzenie do interpretacji jego utworów. Jednym z takich słów jest właśnie „kolejka”. Kolejka jest jednym z tych utworów, które od momentu pojawienia się w przestrzeni literackiej podzieliły opinie Rosjan. Można powiedzieć, że niewielu pisarzy ma tylu zaciętych wrogów, ilu ma ich Sorokin. Nie zdarzało się bowiem wcześniej, by z powodu śmiałych treści wyrażonych za pomocą awangardowej mieszanki językowej demonstracyjnie spuszczano czyjeś dzieła w toalecie ${ }^{5}$. Przyczyn takiego stanu rzeczy można upatrywać przede wszystkim w tym, że śmiałe treści szokowały czytelników, wywołując najczęściej wstręt i obrzydzenie, w najlepszym zaś razie - zawstydzenie. Nagłośnione akcje protestacyjne skierowane przeciwko twórczości pisarza doprowadziły do tego, że Sorokin zyskał status literackiej megagwiazdy, a także ikony postmodernizmu ${ }^{6}$. Pojawienie się tak nieszablonowego utworu jak Kolejka było kolejnym wielkim wydarzeniem literackim i społecznym. Sukces tego utworu w innych krajach pokazal, że inny język nie jest ograniczeniem do zrozumienia przekazu. W Stanach Zjednoczonych powieść została wydana przez „New York Review of Books”. Na język angielski przełożyła ją Sally Laird, brytyjska tłumaczka specjalizująca się w literaturze rosyjskiej. W Polsce Kolejka ukazała się w tłumaczeniu Ireny Lewandowskiej w 1988 roku. Przekład takiego dzieła - niezwykłego nie tylko pod względem treści ale też literackiej

3 Zob. М. Кучерская, Ледовый поход против мясных машин. У Владимира Сорокина новый роман с романом, „Российская газета - Федеральный выпуск” № o(3584); <https://rg.ru/2004/o9/22/sorokin.html> (01.04.2020).

4 Cyt. za: A. Wawrzyńczak, Zbrodnia na literaturze. Powieść „Roman” Wtadimira Sorokina, w: A. Gildner, M. Ochniak, H. Waszkielewicz (red.), Postmodernizm..., S. 185

5 М. Кучерская, Ледовый поход против мясных машин...

6 H. Waszkielewicz, Metafizyka jedzenia. „Końska Zupa” Władimira Sorokina, w: A. Gildner, M. Ochniak, H. Waszkielewicz (red.), Postmodernizm..., s. 169. 
formuły - musiał być jednak dla każdego z tłumaczy sporym wyzwaniem. Trudności przekładowe wynikały m.in. z faktu, że na kartach powieści mamy do czynienia z licznymi zjawiskami podstandardowymi, z którymi praca nie należy do najłatwiejszych (mamy tu na myśli chociażby ograniczenia wynikające z dostępu do źródeł w latach 90.). Kolejka pozbawiona jest tradycyjnej narracji, nie ma w niej opisu realiów, które otaczają jej bohaterów. Zamiast opisu akcji znajdziemy tu wyłącznie dialogi. Taka formą przekazu jest kolejnym eksperymentem pisarza. Język bohaterów jest wystarczająco autentyczny i naturalny, żeby pobudzić wyobraźnię czytelnika. Cała historia osadzona jest w rzeczywistości radzieckiej początku lat osiemdziesiątych. Ludzie czekają w kolejce, przesuwają się do przodu i w ten sposób „popychają" stopniowo fabułę utworu, w którym można dostrzec kilka wątków. Bohaterowie (jest ich wielu, czytelnik zna jednak tylko ich imiona) poruszają różne tematy, zadają liczne pytania. Padają różne określenia przedmiotów, jednak dopiero później okazuje się, że chodzi o deficytowe wówczas towary - odzież i elektronikę. Czytelnik poznaje bohaterów w chwili, kiedy zdradzają oni swoje imiona, innych zaś identyfikuje po sposobie wypowiadania się. Wśród nich są Lena i Wadim, którzy poznają się w kolejce, a potem prowadzą rozmowę. Wynika z niej, że Lena jest młodą dziewczyną, jeszcze się uczy, Wadim zaś jest nieco starszy, ukończył studia. Otacza ich specyficzne uniwersum - świat kolejki. Język bohaterów jest naturalny, nasycony frazeologizmami, wyrażeniami potocznymi i wulgaryzmami. Wypowiedzi mają najczęściej postać zdań pojedynczych, co wydaje się istotne z punktu widzenia przekładu. Można sądzić, że prostota wypowiedzi przełoży się na łatwość ich tłumaczenia. Tak się jednak nie dzieje, ponieważ język bohaterów, jak już wspomniano, zawiera wiele elementów podstandardowych. Należy bowiem zwrócić na przykład uwagę na funkcje wulgaryzmów w tekście, co implikuje ich odpowiednie umiejscowienie w przekładzie. Nie wolno przy tym zapominać o kolokacjach na poziomie neutralnym. Elementy idiostylu Sorokina składają się na przemyślaną i zwartą całość, tak więc ich neutralizacja w przekładzie może uniemożliwić przekazanie zamysłu autora.

Najważniejszą kwestią jest jednak chyba aktualność tej powieści. Utwór oryginalny zawsze będzie reprezentować pewną epokę, będzie kojarzony z czasem, w którym powstał, a także z rzeczywistością, którą opisuje. Kolejkę Sorokin osadził w realiach sowieckich, wydobywając na powierzchnię wszystko to, co było z jego perspektywy warte 
uwagi. Nas interesuje przede wszystkim aspekt lingwistyczny tego eksperymentu. Kolejka przedstawia fragment życia ludzi w czasach Rosji Radzieckiej, życia - na pozór nudnego i przewidywalnego. W momencie, gdy jej bohaterowie zaczynają żartować i opowiadać historie, używając słów uznawanych powszechnie za potoczne czy też wulgarne, tłumacz ma wiele możliwości, by za pomocą odpowiednich technik, wykorzystując swoją kreatywność, stworzyć dzieło, które zainteresuje czytelnika należącego do innej przestrzeni kulturowej. Kolejka to debiut, a zarazem wielki i udany eksperyment, ponieważ zrywa z ramowymi zasadami literatury socrealistycznej. Satyryczny wymiar Kolejki odnosił się do społeczeństwa żyjącego w warunkach stałego niedoboru i mającym do tego deficytu odpowiednie nastawienie. Jednakże najważniejszym jej elementem jest wskazanie na zachowania i relacje międzyludzkie, których zwieńczeniem jest relacja damsko-męska. Ma być ona czymś w rodzaju złotego środka do zdobycia towaru poza kolejką.

Kolejka Władimira Sorokina to utwór zaskakujący rozwiązaniami na poziomie języka, jednocześnie też ujawnia zamiar autora, który chce swojemu czytelnikowi zaserwować terapię szokową7.

Przed analizą przekładu warto postawić kilka pytań, aby określić, czego dokładnie szukamy w języku wyjściowym i docelowym: interesuje nas bowiem, czy tłumaczenie zawiera to, co w utworze oryginalnym jest istotne, czy przekazuje jego sens i wymowę. Zacznijmy zatem od następującego dialogu:

- Товарищ, кто последний?

- Наверно я, но за мной еще женщина в синем пальто.

- Значит я за ней?

- Да. Она щас придет. Становитесь за мной пока8

Przytoczony dialog sprawia wrażenie autentycznej wypowiedzi ustnej. Przypomina nieco relację spisywaną przez dziennikarza, który obserwuje i słucha tego, co się dzieje w kolejce. Z drugiej strony, dialogową formę Kolejki można porównać do praktyk, stosowanych w sztuce pop-art, między innymi w filmach Andy'ego Warhola, tj. na zapisywaniu fragmentu rzeczywistości w takiej postaci, w jakiej się ona ukazuje. W ekranizacji z 1964 zatytułowanej Empire przedsta-

7 L. Mięsowska, Powrót do korzeni. Wtadimira Sorokina język pozarozumowy. „Acta Universitat Lodziensis Folia Litteraria Rossica”. Zeszyt specjalny. Łódź 2013, s. 186.

8 В. Сорокин, Очередъ, Синтаксис, Париж 1985, s. 5. 
wiono na przykład ośmiogodzinną statyczną obserwację wieżowca. Andy Warhol opublikował zaś stenogram 24-godzinnego nagrania rozmowy ${ }^{9}$. Bardzo możliwe, że tego typu zjawiska stały się dla Władimira Sorokina inspiracją do kreowania literackiej rzeczywistości w Kolejce. W zacytowanym fragmencie Sorokin używa słowa „щас”, które pojawia się często w mowie potocznej i nadaje tekstowi znamiona naturalnego dialogu.

W kolejnym fragmencie uwagę zwraca partykuła „Hy”, której występowanie jest typowe dla języka mówionego. Staje się ona tutaj słowem kluczowym, którego wykorzystanie może być traktowane jako celowy zabieg stylistyczny - wzmacnia w przytoczonym dialogu znaczenie następujących po niej czasowników występujących w formie trybu rozkazującego ${ }^{10}$ :

- Ну, скажите, не вредничайте.

- Hea.

- Ну, скажите, пожалуйста.

- Ну, а зачем вам?

- Ну, что вам жалко что ли?"1

Interesujące więc staje się zbadanie, jak ten zabieg językowy został odzwierciedlony w przekładzie:

- No, niech pani powie...

- Niee.

- A ja proszę.

- A na co to panu?

- No co pani szkodzi? ${ }^{12}$

Wskazana partykuła posiada bezpośredni ekwiwalent w języku polskim, tj. „no”. Jednak w przekładzie został on wykorzystany zaledwie jeden raz. Można więc przypuszczać, że zamysł autora nie znalazł

9 W. Sorokin, Kolejka, przeł. I. Lewandowska, Tower Press, Gdańsk 2005, s. 11.

${ }^{10}$ Zob. C.M. Колесникова, Фундаментальная наука вузам, разграничение частиц и междометий в предложении-высказывании, https://cyberleninka. $\mathrm{ru} /$ article/n/razgranichenie-chastits-i-mezhdometiy-v-predlozhenii-vyskazyvanii (01.04.2020).

${ }^{11}$ В. Сорокин, Очередъ..., s. 10.

${ }^{12}$ Н.Н. Андреева, Роман В. Сорокина „Очередъ” форма в контекстре проблемы репрезентации в искусстве московского концептуализма. „Вестник СанктПетербургского университета”, серия 9, выпуск 4, https://cyberleninka.ru/ article/n/roman-v-sorokina-ochered-forma-v-kontekste-problemy-reprezentatsii-v-iskusstve-moskovskogo-kontseptualizma (03.02.2020). 
odzwierciedlenia w polskim tekście. Zakładając, że tłumacz postąpiłby analogicznie jak Sorokin, otrzymalibyśmy dialog w następującej postaci:

- No, niech pani powie...

- No, nie powiem.

- No, ale ja proszę.

- No dobra, a po co to panu?

- No, a co pani szkodzi?

Wydaje się więc, że partykuła „no”13 mogłaby być odpowiednikiem rosyjskiego „Hy”, a także analogicznie zapełnić określone miejsca w dialogu. Tłumacz najwyraźniej nie zwrócił uwagi na jej funkcje w języku oryginału, w związku z czym nie dostrzegł konieczności jej zachowania, choć mogłaby ona nadać odpowiednim fragmentom nieco ekspresji. Byłoby to wskazane, zważywszy, że nie występują $\mathrm{w}$ nich formy trybu rozkazującego. W języku rosyjskim użycie tej partykuły jest dość powszechne. Podobnie powszechna jest partykuła „no” w języku polskim, co jednak nie znalazło odzwierciedlenia w przekładzie.

Każdy literacki eksperyment powinien zachęcać tłumacza do gry z tekstem oryginalnym. Taką zachętę odnajdujemy w tekstach Sorokina często. Ilustruje to, na przykład, poniższy fragment:

- Ух ты, тяжелая какая! Как вы несли такую?

- Так и несла.

- А что здесь - гантели?

- Книги ${ }^{14}$.

- Och, jaka ciężka! Jak pani ją niosła?

- Jakoś niosłam.

- Co tam jest w środku - ołów?

$-\mathrm{Książki}^{15}$.

Odpowiedzią polskiego tłumacza na rosyjskie „гантели” stał się „ołów”. Zastosowanie takiej transformacji leksykalnej jest akceptowalne, choć w analogicznych sytuacjach w języku polskim mówimy raczej o cegłach. Jeśliby więc zastosować taki właśnie ekwiwalent, otrzymalibyśmy dialog w następującej postaci:

${ }^{13}$ M. Szymczak, Stownik języka polskiego, t. II, Warszawa: PWN 1979, s. 384.

${ }^{14}$ В. Сорокин, Очередъ..., s. 11.

${ }^{15}$ W. Sorokin, Kolejka..., s. 13. 
- Och, jaka ciężka! Jak pani ją niosła?

- Jakoś niosłam

- Niosła pani chyba cegły w tej torbie

- Ta, od razu cegły. Książki.

Cegły pojawiają się w języku polskim jako jeden z elementów charakteryzujących damskie torebki ${ }^{16}$.

$\mathrm{W}$ innych dialogach uwagę zwracają też leksemy wyrażające ekspresję, np. W formie wykrzykników. Jednym z nich jest „фy”, które w polskim przekładzie zostało przekazane jako „fu”. Budzi to pewne wątpliwości, bowiem biorąc pod uwagę fakt, że dialog powinien być możliwie autentyczny, wprowadzenie wykrzyknika w takiej postaci tę autentyczność zaburza. Słowo takie oczywiście istnieje, ale w języku polskim w analogicznych sytuacjach stosuje się zwykle wykrzyknik „fuj”.

- Ффуу... что... что такое...

- Дядь! Дядь!

- Чего... чего такое... что...

- Дядь!

- Ну чего тебе?

- Вы это... встаньте, пожалуйста. А то там это...

- Что это?... фу... ${ }^{17}$

- Oj, kurwa... fuuu...

- Proszę pana. Proszę pana... proszę pana!

- Ffuu... co... co się stało...

- Proszę pana!

- Czego... czego... co...

- Proszę pana! Proszę pana!

- No, czego chcesz?

- Niech... niech pan wstanie, dobie? Bo on tam leży...

- Kto leży?... fu.... ${ }^{18}$

Zastosowanie tego odpowiednika można więc uznać za niezbyt udany zabieg translatorski

${ }^{16}$ Buty, rajstopy... Co jeszcze przeciętna kobieta nosi w torebce?, https://archiwum. radiozet.pl/Rozrywka/O-tym-sie-mowi/Co-kobieta-ma-w-torebce-TOP-10rzeczy-z-damskiej-torebki-RANKING-00009509. „Pusta torba to około 500-700 gramów. Załadowana - przeciętnie 2,5 do 3 kilogramów. To tak, jakbyś nosiła przy sobie cegłę!; Co jeszcze przeciętna kobieta nosi w torebce? [...] Mężczyźni naśmiewają się, że w kobiecej torebce można znaleźć wszystko - nawet cegły" (23.12.2019).

17 В. Сорокин, Очередъ..., s. 164.

${ }^{18}$ W. Sorokin, Kolejka..., s. 147. 
Jak zauważamy, polskie tłumaczenie zaczyna się od wulgaryzmu, chociaż w oryginale go nie ma. Nie oznacza to, oczywiście, że nie wolno w związku z tym go użyć, ale jego pojawienie się w tym miejscu nie jest chyba dobrym rozwiązaniem. Wykrzyknienie „fuj” użyte zamiast „fu” również brzmiałoby nienaturalnie, mimo że w taki sposób wyraża się obrzydzenie. Należałoby w związku z tym zastosować inny wyraz odpowiedni do sytuacji. W języku polskim w mowie potocznej często stosuje się w analogicznych sytuacjach leksem „tfu”, który nie tylko wyraża obrzydzenie i pogardę, ale może też imitować splunięcie, jeżeli zostanie użyty w formie wykrzyknika ${ }^{19}$. W tym kontekście jego użycie byłoby nie tylko trafne, ale zwiększyłoby też wymiar perswazyjny wypowiedzi:

- Jasna cholera... tfu!...

- Proszę pana. Proszę pana... proszę pana!

- Tfuu!... czego... co się dzieje...

- Proszę pana!

- No co... czego... co...

- Proszę pana! Proszę pana!

- No, czego chcesz?

- Niech... niech pan wstanie, dobie? Bo on tam leży..

- Kto leży?... tfu!...

Podobnym przykładem jest zdanie zawierające wyrażenie „ух ты”. W języku polskim możliwe jest użycie analogicznego zwrotu „uch ty”, który jednak może być uznany za rusycyzm. W kilku fragmentach tłumaczka wykorzystała więc inny ekwiwalent, typowy dla języka polskiego, a mianowicie „och”:

- Ух ты, тяжелая какая! Как вы несли такую?

- Och, jaka ciężka! Jak pani ją niosła?

Jednakże w kolejnym przykładzie, który przytaczamy poniżej, występuje wykrzyknik „och” w połączeniu z zaimkiem osobowym. Sam leksem „och” eksplikowany jest przez Stownik wspótczesnego języka polskiego jako okrzyk wyrażający lub podkreślający intensywność wyrażanych różnych stanów uczuciowych ${ }^{20}$. Jednak połączenie go z zaimkiem jest nienaturalne. Możliwe są inne rozwiązania, bowiem

${ }^{19}$ Stownikwspótczesnegojęzyka polskiego, t. 2, Przegląd Reader's Digest, Warszawa 1998, s. 425.

${ }^{20}$ Słownik współczesnego języka polskiego, t. 1, Przegląd Reader’s Digest, Warszawa 1998, s. 642. 
w polskim języku potocznym można bez problemu znaleźć takie kolokacje słowne jak: „a niech cię”; „o ja cię kręcę” czy „niech to diabli”. Rosyjskie wyrażenie „yx ты” ma podkreślić i wzmocnić znaczenie następującego po nim słowa. Jest to charakterystyczne dla wyrażeń potocznych lub slangowych.

- Ой, насиделась, нога онемела...

- Идем, идем скорей...

- Ух ты, а тут тоже порядком народу... ${ }^{21}$

- Oj, nasiedziałam się, noga mi zdrętwiała...

- Chodźmy, chodźmy szybciej...

- Och ty, a tutaj też pełno ludzi...22

W innych fragmentach, w których w języku wyjściowym występuje yx mы, w polskim przekładzie pojawia się natomiast „uch ty”:

- Хороший чай?

- Хороший.

- Ух-ты... очередь какая... ${ }^{23}$

- Dobra herbata?

- Dobra.

- Uch ty, ale kolejka... ${ }^{24}$

W języku polskim istnieje jednak co najmniej kilka innych odpowiedników, które mogłyby takie znaczenie przekazać, jak, na przykład, zwrot z dwiema partykułami - „Ożeż ty!”.

- Dobra herbata?

- Dobra.

- Ożeż ty! Ale kolejka...

Można ponadto zastosować kolokację - „a niech to”.

- Chodźmy, chodźmy szybciej...

- A niech to! Tutaj też pełno ludzi...

- Dobra herbata?

- Dobra

- A niech to! Ale kolejka...

${ }^{21}$ В. Сорокин, Очередъ..., s. 93.

${ }^{22}$ W. Sorokin, Kolejka..., s. 83.

${ }^{23}$ В. Сорокин, Очередъ..., s. 104.

${ }^{24}$ W. Sorokin, Kolejka..., s. 92. 
Powszechnie występujące $\mathrm{w}$ mowie potocznej i częste w tekstach Sorokina kolokacje stają się kolejnym wyzwaniem dla tłumacza, bowiem o ich znaczeniu, a co za tym idzie - o wyborze odpowiedniego ekwiwalentu, decyduje wyłącznie kontekst. Jak się jednak okazuje, czasami intuicja tłumacza zawodzi. Zwróćmy na przykład uwagę na rosyjski zwrot „не надо”. Pierwszym odpowiednikiem, który nasuwa się Polakowi, jest wyrażenie „nie trzeba”. Jednakże taki ekwiwalent nie w każdym kontekście jest zgodny z normą języka polskiego:

— НЕ НАДО ПИХАТЬСЯ, ТОВАРИЩИ! ИНАЧЕ Я БУДУ ВЫВОДИТЬ! 25

W polskim tłumaczeniu ów związek wyrazowy brzmi:

- NIE ROZPYCHAĆ SIĘ, TOWARZYSZE! BO ZACZNĘ USUWAĆ Z KOLEJKI! ${ }^{26}$

Podobnie w przykładzie przytoczonym poniżej:

- Да и красивее ткань намного.

- Володя, не надо бросаться.

- А кошка проворней тебя ${ }^{27}$.

- I materiał znacznie ładniejszy.

- Wołodia nie rzucaj kamieniami.

- Kot jest sprytniejszy od ciebie ${ }^{28}$.

Jak widać, w przekładzie zastosowano formę trybu rozkazującego. Wydaje się to trafne, bowiem kontekst nie daje tu tłumaczowi innych możliwości. W kolejnym fragmencie natomiast rosyjskie „не надо” zostało przetłumaczone jako „nie trzeba”:

- Ты знаешь... наверно за последние пять лет это у меня самый чудесный вечер.

- Правда?

- Да...

- А почему?

- Потому что... потому что...

- Вадим... Вадим...

- Прелесть моя... очарование...

25 В. Сорокин, Очередъ..., s. 25.

${ }^{26}$ W. Sorokin, Kolejka..., s. 25.

${ }_{27}$ В. Сорокин, Очередъ..., s. 41.

${ }^{28}$ W. Sorokin, Kolejka..., s. 41. 


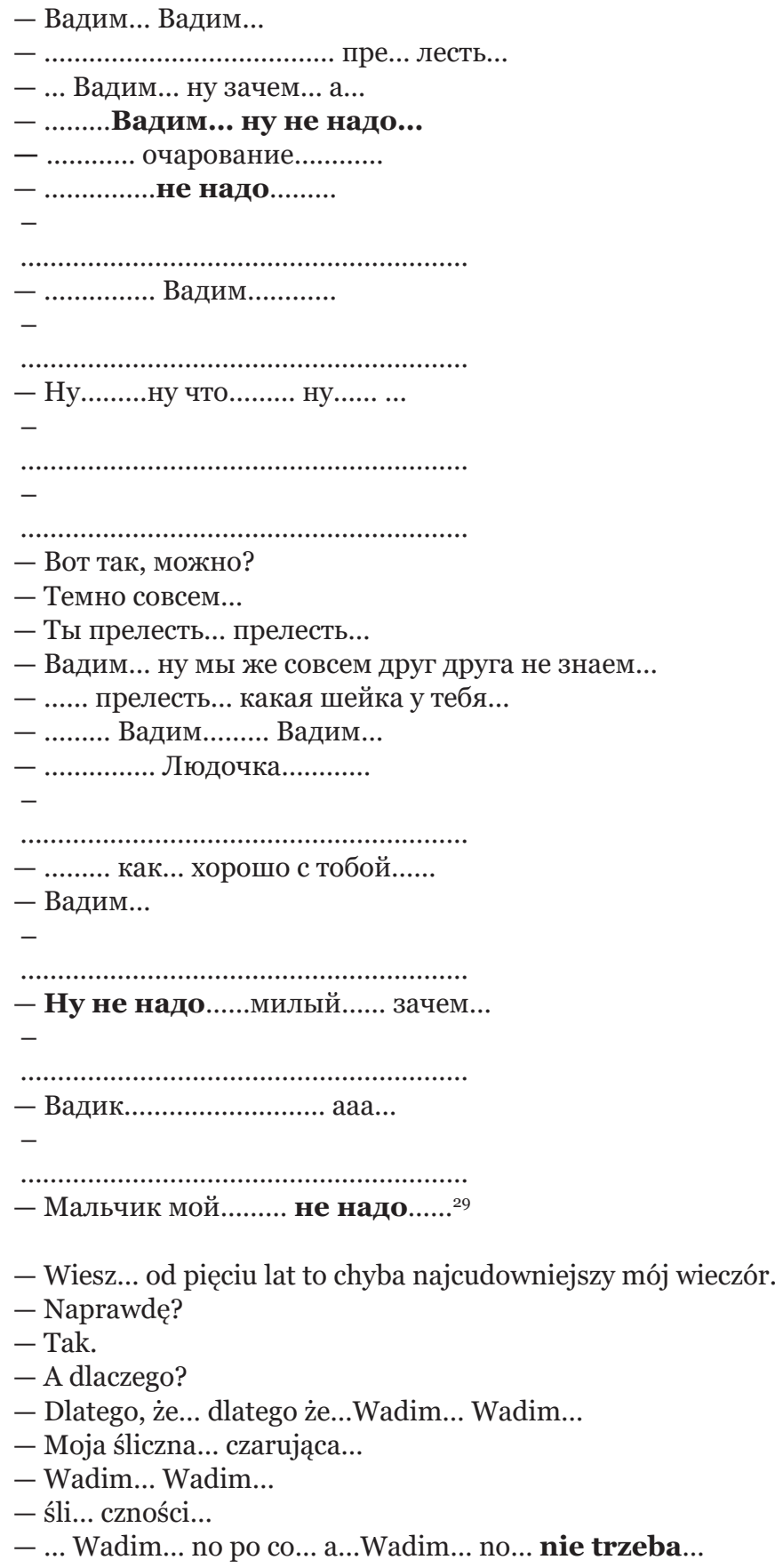

${ }^{29}$ В. Сорокин, Очередъ..., s. 196. 
- czarowna

- nie trzeba, Wadim....

- No no co no

- a tak mogę?

- Zupełnie ciemno...

- Jesteś cudowna... cudowna...

- Wadim... my się przecież prawie w ogóle nie znamy...

- śliczności... jaką masz szyjkę....

- Wadim Wadim

- Ludeczko... jak dobrze z tobą

- Wadim...

- No nie trzeba mój mily po co. Wadik aaa

Mój chłopczyku nie trzeba ${ }^{30}$.

Analizując ten fragment powieści, można powiedzieć, że czytelnik zostaje wprost zaciągnięty do sypialni, gdzie staje się świadkiem wszystkiego, co się w niej pomiędzy Wadimem a Ludą wydarzy. Scena ta nie przedstawia zwykłąej relacji dwojga ludzi, której zwieńczeniem jest zbliżenie intymne. Jej zadaniem jest przede wszystkim wskazanie na to, jak są wywierane wpływy za pomocą metod, nazwijmy to - naturalnych, bowiem sfera seksualna przestaje być tutaj tematem tabu. Nie pozostawia to żadnych wątpliwości co do zasad obowiązujących w społeczeństwie totalitarnym ${ }^{31}$. Wyrażenie „не надо”, przetłumaczone tutaj jako „nie trzeba”, staje się w tym kontekście kalką językową i zmienia znaczenie wypowiedzi. W oryginale sygnalizuje ono początkowy sprzeciw bohaterki wobec zalecającego się do niej mężczyzny. To znaczenie nie zostało zachowane w przekładzie, choć język polski daje takie możliwości. W intymnej sytuacji, o której mowa w powieści, odpowiednie byłyby, na przykład, takie wyrażenia jak „przestań”; „co ty wyprawiasz”; „oszalałeś” czy też „zawstydzasz mnie”; „proszę cię, przestań”...

W procesie poszukiwań ekwiwalentu powinna więc obowiązywać zasada sprawdzenia tego, co w konkretnej sytuacji powiedziałby rodzimy użytkownik języka.

W tej samej scenie, w domu Ludmiły ponownie pojawia się omawiane wcześniej „фу”: „Фууу... ты обалденная женщина... фууу”з2. W polskim przekładzie natomiast mamy: „Fuu... co za kobieta... fu...”33. I dalej - „Фууу... ааа..., Что такое? Да вспомнил про оче-

${ }^{30}$ W. Sorokin, Kolejka..., s. 177.

${ }^{31}$ A. Wawrzyńczak, Zbrodnia na literaturze..., s. 184.

$3^{32}$ B. Сорокин, Очередъ..., s. 204.

${ }^{33}$ W. Sorokin, Kolejka..., s. 187. 
редь эту пакостную... черт побрал бы...” ${ }^{34}$ w polskim przekładzie otrzymujemy analogicznie: „Fuuu.., aaa... Co znowu? Przypomniałem sobie tę wstrętną kolejkę... żeby to diabli wzięli...”.

W języku rosyjskim „фy” opisywane jest jako wyraz wieloznaczny, co oznacza, że przy ustalaniu jego znaczenia istotny jest kontekst. Oprócz znaczenia wstrętu czy pogardy może ono występować jako wyraz uczucia ulgi, odciążenia ${ }^{35}$. W powieści Kolejka jest ono, jak się wydaje, istotnym elementem gry z czytelnikiem. Niestety, tłumacz nie zawsze sobie z nią radzi w sposób zadowalający. W zdaniu „Fuu... co za kobieta... fuu...” użycie „fuu” skłania do zrozumienia całej frazy jako wyrażenia wstrętu.

Przytoczone fragmenty potwierdzają fakt, że Kolejka Władimira Sorokina to utwór nasycony elementami gier językowych, będący doskonałym przykładem awangardowej sztuki zestawiania i łączenia wyrazów. Pokazuje, jak duże znaczenie ma dla pisarza zabawa (z) językiem i nie chodzi tu tylko o opis otaczającej rzeczywistości.

W polskim przekładzie Kolejki nie uwzględniono wszystkich zjawisk podstandardowych i nie wykorzystano w pełni możliwości języka polskiego. Analiza nawet kilku fragmentów pokazuje, że w języku przekładu dysponujemy odpowiednimi środkami pozwalającymi zachować analogiczne funkcje tych zjawisk. Kolejka ze swoimi barwnymi dialogami ma prowokować, wywoływać emocje, a nawet szokować. Polskie tłumaczenie zawiera oczywiście te elementy oryginału, które w dalszym ciągu pozwalają traktować tę powieść jako pewną prowokację, niemniej niedopracowane szczegóły ten odbiór modyfikują. Dzieło, które zostało przyjęte w Rosji tak burzliwie, polaryzując silnie odbiorców, raczej nie powinno tracić siły oddziaływania w innej przestrzeni językowej. Dlatego też Władimir Sorokin z dumą, ale i z triumfem mógłby dzisiaj o sobie powiedzieć „nie ma sensu udawać, że mnie nie ma”.

\section{REFERENCES}

Andreyeva, Natal'ya. "Roman V. Sorokina Ochered' forma v kontekstre problemy reprezentatsii v iskusstve moskovskogo kontseptualizma." Vestnik Sankt-peterburgskogo universiteta, seriya 9, vypusk 4, <https://cyberleninka.ru/article/n/ roman-v-sorokina-ochered-forma-v-kontekste-problemy-reprezentatsii-v-is-

${ }^{34}$ В. Сорокин, Очередъ..., s. 207.

${ }_{35}$ Словарь русского языка (MAC), http://feb-web.ru/feb/mas/mas abc/21/ma458605.htm?cmd=o\&istext=1 (29.01.2020). 
kusstve-moskovskogo-kontseptualizma> [Андреева, Наталья. "Роман В. Сорокина 'Очередь' форма в контекстре проблемы репрезентации в искусстве московского концептуализма.” Вестник Санкт-Петербургского универcumema. Серия 9, выпуск 4, <https://cyberleninka.ru/article/n/roman-vsorokina-ochered-forma-v-kontekste-problemy-reprezentatsii-v-iskusstve-mos kovskogo-kontseptualizma> ].

Buty, rajstopy... Co jeszcze przeciętna kobieta nosi $w$ torebce?, 11 sierpnia 2015, <https://archiwum.radiozet.pl/Rozrywka/O-tym-sie-mowi/Co-kobieta-ma-wtorebce-TOP-10-rzeczy-z-damskiej-torebki-RANKING-00009509>.

Kolesnikova, Svetlana. Fundamental'naya nauka vuzam, razgranicheniye chastits i mezhdometiy $v$ predlozhenii-vyskazyvanii. Prepodavatel' XXI vek, <https:// cyberleninka.ru/article/n/razgranichenie-chastits-i-mezhdometiy-v-predlozhenii-vyskazyvanii> [Колесникова, Светлана. Фундаментальная наука вузам, разграничение частиц и междометий в предложении-высказывании. Преподаватель XXI век, <https://cyberleninka.ru/article/n/razgranicheniechastits-i-mezhdometiy-v-predlozhenii-vyskazyvanii> ].

Kucherskaya, Mayya. "Ledovyy pokhod protiv myasnykh mashin. U Vladimira Sorokina novyy roman s romanom." Rossiyskaya gazeta - Federal'nyy vypusk № o(3584); https://rg.ru/2004/o9/22/sorokin.html [Кучерская, Майя. “Ледовый поход против мясных машин. У Владимира Сорокина новый роман с романом.” Российская газета - Федеральный выпуск № о(3584); <https://rg.ru/2004/o9/22/sorokin.html>].

Mięsowska, Lidia. "Powrót do korzeni. Władimira Sorokina język pozarozumowy." Wspótczesny dramat rosyjski: kontynuacje i przemiany. Acta Universitatis Lodziensis Folia Litteraria Rossica. Zeszyt specjalny. Łódź: Wydawnictwo Uniwersytetu Łódzkiego, 2013.

Slovar' russkogo yazyka (MAC). <http://feb-web.ru/feb/mas/mas abc/21/ma458605.htm?cmd=o\&istext=1> [Словарь русского языка (MAC). <http://feb-web.ru/feb/mas/mas abc/21/ma458605.htm?cmd=o\&istext=1 $>$ ]

Sorokin, Vladimir, Ochered', Parizh: Sintaksis, 1985 [Сорокин Владимир, Очередь, Париж: Синтаксис, 1985].

Sorokin, Vladimir. V Rossii proshloye s"yelo nastoyashcheye, a nastoyashcheye s"yelo budushcheye. <https://ria.ru/20110926/443966831.html [Сорокин, Владимир, В России прошлое съело настоящее, а настоящее съело будущеe, <https://ria.ru/20110926/443966831.html>.

Sorokin, Władimir. Kolejka. Transl. Lewandowska, Irena. Gdańsk: Tower Press, 2005 .

Szymczak, Mieczysław. Stownik języka polskiego. T. II. Warszawa: PWN, 1979.

Waszkielewicz, Halina. "Metafizyka jedzenia. 'Końska zupa’ Władimira Sorokina.” Postmodernizm rosyjski i jego antycypacje. Gildner, Anna, and Ochniak, Magdalena, and Waszkielewicz, Halina (eds.). Kraków: Collegium Columbinum, 2007.

Wawrzyńczak, Aleksander. “Zbrodnia na literaturze. Powieść 'Roman' Władimira Sorokina." Postmodernizm rosyjski i jego antycypacje. Gildner, Anna, and Ochniak, Magdalena, and Waszkielewicz, Halina (eds.). Kraków: Collegium Columbinum, 2007.

Wierzbicka, Elżbieta. Stownik współczesnego języka polskiego. T. 1-2. Warszawa: Przegląd, 1998. 